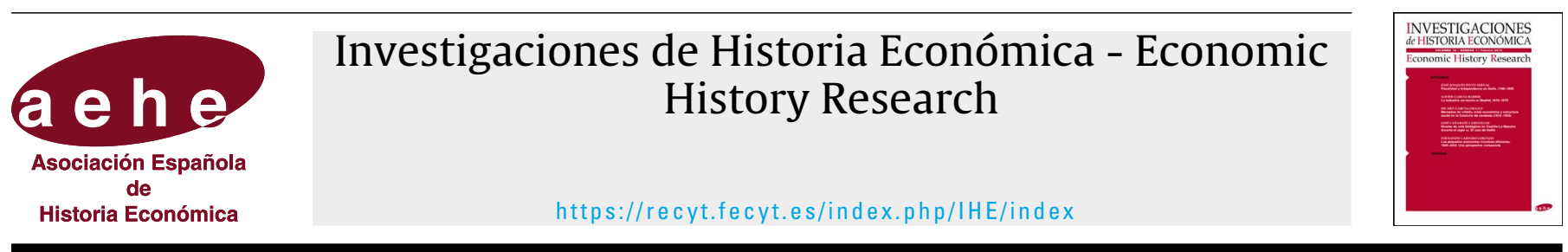

Artículo

\title{
Economic effects of the Black Death: Spain in European perspective
}

\author{
Carlos Álvarez-Nogal* (D) \\ Universidad Carlos III de Madrid

\section{Leandro Prados de la Escosura ID \\ Universidad Carlos III de Madrid}

\section{Carlos Santiago-Caballero (DD}

Universidad Carlos III de Madrid

\section{ARTICLE INFO}

\section{Article history:}

Reception: 22 mayo 2020

Acceptance: 15 septiembre 2020

On-line: 1 diciembre 2020

\section{JEL classification:}

I10

N13

N33

052

\section{Keywords}

Black Death

Frontier economy

Malthusian economy

Spain

\begin{abstract}
A B S T R A C T
The Black Death was the most devastating demographic shock in recorded human history. However, the effects in the European population were highly asymmetrical as were its economic consequences. This paper surveys the short and long run economic effects of the plague in Spain in European perspective. While the demographic impact in Spain was moderate compared to the European average, the economic effects were more severe and incomes per head fell sharply. This was a consequence of the existence of a frontier economy in Spain characterised by a relative scarcity of labour and a fragile equilibrium between factors of production. Unlike most of Europe, in Spain the Black Death increased inequality as the remuneration of labour decreased more rapidly than proprietors' gains. In the long term the Plague reinforced the frontier economy status.
\end{abstract}

@ 2020 Asociación Española de Historia Económica

\section{Los efectos económicos de la peste negra: España en perspectiva europea}

\section{R E S U M E N}

La peste fue el shock demográfico más devastador registrado en la historia de la humanidad. Sin embargo, los efectos en la población europea y en sus economías fueron asimétricos. Este trabajo estudia los efectos económicos de la peste en España en el corto y largo plazo en perspectiva europea. Mientras que el impacto demográfico en España fue moderado comparado con la media europea, los efectos económicos fueron más severos y el ingreso per cápita descendió abruptamente. Esto se debió a la existencia de una economía de frontera en España caracterizada por la escasez de trabajo y un frágil equilibrio entre los factores de producción. Al contrario que en la mayoría de Europa, en España la peste incremento la desigualdad al descender la remuneración del trabajo más rápidamente que las ganancias de los propietarios. En el largo plazo la peste reforzó el estatus de economía de frontera.

@ 2020 Asociación Española de Historia Económica

\footnotetext{
*Corresponding author. Email: canogal@clio.uc3m.es
} 


\section{Introduction}

The Black Death was one of the first truly global events in human history (Carpentier, 1972). Since its arrival to Europe in 1347 , it quickly spread over the continent bringing a considerable loss of human lives and severe economic and social consequences. Plagues were not something new in Spain or Europe, and bouts of plague would appear regularly in the following centuries up to the present (Pérez Moreda, 1980). The difference between the Black Death and previous epidemic experiences relies on the severity of the shock in a very short period of time, and the return of the disease without cure that appeared recurrently (Biraben, 1976). The incidence of the plague was asymmetrical in Europe, partly as a consequence of the different economic and social characteristics of the areas affected. Spain and, especially, Castile have been traditionally considered as some of the regions where the impact of the Black Death was milder (Voigtländer and Voth, 2013).

The conditions to face a global pandemic were not the best in the Middle Ages. There were difficulties to storage food to survive during shortage periods, sudden and intense climate alterations, low ability to increase personal savings, and underdeveloped financial and insurance markets ${ }^{1}$. Medical knowledge was limited as were medicines, and the social and political framework did not help to smooth any of these problems with inequality reinforcing the worst consequences of any crises. While medieval societies struggled to barely deal with all these problems ordinarily, they were not prepared to face a powerful killer disease like the Black Death. The pandemic was an external shock that hit societies and people regardless their economic and social status (Alfani and Murphy, 2017, p. 335). Facing the pandemic, lawmakers in the Middle Ages reacted introducing legislation that was not so different to the responses that we can observe in the present. To contain the spread of the virus, the Castilian Cortes of 1351 prohibited the presence of beggars in the streets and established working hours and rest periods. They also tried to control the access to certain items limiting their prices.

Some authors argue that a deeply rooted and long process of economic decadence had already started in Europe when the plague arrived to its borders (Hilton, 1980, p. 38). According to this Malthusian interpretation of history, the demographic growth of the Middle Ages brought European population near to its ceiling adding pressure on resources. The fragile equilibrium between both was broken when deteriorating climatic conditions reduced harvests and produced subsistence crises that made more probable the appearance of disease. The agrarian crises of 1315-17 and 1340-50 were therefore examples of such process, and the demographic decline was already under way fifty years before the arrival of the Black Death in some areas of Europe (Février, 1966) ${ }^{2}$. The plague was so lethal because it reached Europe at a time when

\footnotetext{
${ }^{1}$ For a detailed analysis of several factors that played a role in the fourteenth century crisis see Bourin et al. (2011).

2 Some authors have shown depopulation of lands before the arrival of the plague. This is a contradictory argument, as more available land would have released Malthusian constrains and reduced the problems with food supply. Understanding the political reality of the Iberian Peninsula at the time, we make use of the term Spain as the aggregation of the territories comprised today in the country, that the readers would understand is used for convenience.
}

its population was already weakened by famines. In the Spain, part of the literature accepts the existence of problems and famines before the Black Death (Monteano, 2001; Berthe, 1984), explained by unfavourable climatic conditions that produced bad harvests but did not stop the growth that started two centuries before (Larenaudie, 1952; Carpentier, 1962). Other authors like Schofield (2013) pointed out to the role that land markets and rural financial institutions played in the development of famines in the middle ages.

Therefore, from this point of view the origin of the crisis of the fourteenth century was not an exogenous shock that changed the trend of the cycle, because endogenous Malthusian forces were already operating from long before. This research line was defended by authors such as Postan or Abel, who saw in the Black Death another consequence of the overpopulation and unfair social structures of the late Middle Ages and the first stages of the transition to capitalism (Postan, 1981; Abel, 1967) ${ }^{3}$. However, this view is contested by the fact that the Black Death affected equally to both rich and poor and that therefore weakens the connection between hunger and mortality (Biraben, 1976; Alfani and Murphy, 2017, p. 325) ${ }^{4}$. Other authors like Campbell (2016) point that exogenous environmental factors could have played an important role in the development and spread of the plague.

Unlike the rest of Europe, in Spain the economic consequences of the Black Death at macroeconomic levels have received little attention ${ }^{5}$. The main studies on the effects of the Black Death in Spain focus on very specific factors such as increasing mortality, depopulation, declining agrarian output, prices and wage increases, and fall of land rents (Cabrillana, 1968; Ladero Quesada, 1981; Valdeón Baruque, 1972a). The lack of empirical evidence at macroeconomic level also explains why most of the Spanish literature is based on local or regional studies. Most of the research concerns the routes of propagation and the factors behind $\mathrm{it}^{6}$, the epidemiological characteristics ${ }^{7}$, the incidence of the plague in different social groups $^{8}$, and its cultural and social effects ${ }^{9}$. However, the economic consequences of the plague have not been considered at a national scale including the long-term effects of the disease ${ }^{10}$.

While in most of Europe the Black Death produced an intense demographic shock that prompted an improvement of

\footnotetext{
${ }^{3}$ See also Perroy (1949).

${ }^{4}$ Rubio Vela (1987) believes the same for the case of Valencia.

${ }^{5}$ Among others, see Vicens Vives (1957, pp. 81-82, 230-31), Vilar (1987), Carpentier (1962). Some express their pessimism for the bad quality of quantitative sources compared to the Italian case (Valdeón Baruque, 1984, pp. 1048-49)

${ }^{6}$ Amasuno Sárraga (1994); Vaca Lorenzo (2001, pp. 32-33) collects bibliography to define the spread of the plague at municipal level with contemporary chronicles. Cabrillana (1968) is a first attempt to establish a timeline and routes. See also Amasuno Sárraga (1994;1996) and Ubieto (1975), who suggests a North-South spread from Santiago de Compostela. Other authors suggest the existence of several entry points (Monteano, 2001, p. 104; Sobrequés Callicó, 1970).

${ }^{7}$ Arrizabalaga (1991). For a description of the disease and varieties see Vaca Lorenzo (2001, p. 27).

${ }^{8}$ Ibid., p. 27.

${ }^{9}$ See Verlinden (1938), Amasuno Sarra (1996, p. 69), López de Meneses (1959), Mollat et al. (1976, p. 97), and Sobrequés (1970, pp. 80-81).

${ }_{10}$ Rodríguez's survey provides an exception (Rodríguez, 2011).
} 
real wages in the long term, in Spain the effect on real salaries was less intense. In the same line, in Europe the Black Death produced a sudden increase of incomes per capita, but recent research show that in Spain incomes per head fell sharply (Álvarez-Nogal and Prados de la Escosura, 2013). Why do we observe these differences between Spain and the rest of Europe? What were the reasons behind them? What were the long term consequences of the Black Death in Spain and in its role within the Little Divergence? This paper will address these crucial questions looking at the European experience. We will firstly focus on population as the most important demographic and visible dimension of the crisis. Secondly, we will address the effects on income per head as the most relevant economic aspect, and we will later estimate the consequences on inequality as a key social dimension with also strong economic ramifications.

\section{Population}

Subsistence crises were common at the beginning of the fourteenth century. The Iberian Peninsula was not an exception, and experienced its own crises in three different waves (1302-1303, 1333-1335, and 1343-1347) (Ladero Quesada, 1981, p.3). In the eastern coast famines appear to be milder, although food shortages were also identified between 13101314 and 1324-1329 (Rubio Vela, 1987). In Castile, lawmakers pointed out to causes that were beyond the direct effects of the plague. The Cortes gathered in Valladolid in 1325 considered that the poverty that affected the territory was consequence of "bad years" (López Alonso, 1978, p. 484). Valdeón Baruque (1969; 1972b) found the origin of the crisis in Castile in the famines of the early 1330s. Bad weather, wars, and subsequent plunder led to a reduction in grain production and was debated in the different Cortes gathered during the fourteenth century (Vaca Lorenzo, 2001, p. 47). The reduction in population in areas like Tierra de Campos was noticed years before the arrival of the plague (Vaca Lorenzo, 1977, p. 379). The increase of prices and nominal wages as a consequence of the demographic decline also affected other regions like Navarre (Monteano, 2001, p. 103). The arrival of the Black Death intensified the demographic decline and brought disturbances to the rural world (Cabrillana, 1972, p. 31). Social conflict intensified, public works paralysed, and land concentrated in a smaller number of hands (Gautier-Dalché, 1962). Vilar summarised the situation in Catalonia in a rather catastrophic picture with abandonment of properties, deaths of prominent figures, reduction of rents, regulation of salaries, massacres of Jews, and generalised depopulation (Vilar, 1987, pp. 147-149) ${ }^{11}$. Feliú also accepts the demographic impact of the plague, but argues that its impact on the economy was considerably more limited (Feliú, 2004) ${ }^{12}$.

However, most of the research concerning the demographic effects of the Black Death in Spain suggest that the population loss was considerably lower than in other regions of

\footnotetext{
${ }^{11}$ In Catalonia the Black Death is related to the crisis of the late Middle Ages and the social fight of the remensas (Vicens Vices, 1945).

${ }^{12}$ Revising the position defended by Vilar and Vicens Vices, Feliú argues that the Black Death should be understood as part of a long process of economic hardship in Catalonia and not as its origin (Feliú, 2004)
}

Europe (Trenchs Odena, 1969). They also reflect that there were significant regional differences within Spain, mainly between Castile and Aragon ${ }^{13}$. In Castile there were few contemporary mentions to the effects of the plague (Escalona, 1782, p. 172). It was estimated that the population of Castile was around 3 million in 1300, 2.5 million in 1400 and 4 million in 1490 (Iradiel et al., 1989, pp. 472-473). According to these estimates population only fell by around $16 \%$ between 1300 and 1400, implying that recurrent epidemic waves that followed during the second half of the fourteenth century were not as virulent as in other parts of Europe, where between one-third and one-half of the population was wiped out (Campbell, 2016, p. 354) ${ }^{14}$. Focusing on the most immediate years after the plague, Castán Lanaspa (2020) estimates that the demographic loss in Castile was around 20\%. Within Castile, the centre and the north were probably the areas less affected. On the other hand, Vaca Lorenzo (1977) argues that Andalusia in the south was probably the worst hit area of the region, and that most of the reduction in population levels in the north of Castile were consequence of north-south domestic migrations, where migrants from areas like Tierra de Campos repopulated de south ${ }^{15}$.

In Aragon the effects were also geographically asymmetrical. In some areas of the coast like Castellón there are no mentions to the plague during its first wave (Doñate Sebastiá, 1969). Recent studies estimate that in Catalonia the loss during the worst years of the plague was around $20 \%$ while the decrease in Aragon would be closer to $30 \%$ (Castán Lanaspa, 2020). Regions in the interior like Teruel present significantly higher loses of around 35\%, although most of that reduction can be explained, like in Castile, by internal migrations to other regions like Barcelona, Valencia or Zaragoza (Sobrequés Callió, 1970). Other areas of Spain present a more controversial evidence. In the case of Navarre, some authors argue that the plague had a substantial effect in the number of deaths, revealing population loses of around $43 \%$ (Vaca Lorenzo, 1977, p. 91). By 1427 the population in the region would have been one quarter lower of the levels reached in 1346 in line with the results observed in other areas of Europe (Monteano, 2001, p. 118; Blockmans and Dubois, 1997, p. 208). On the other hand, more recent studies suggest that mortality levels in Navarre were considerably lower ${ }^{16}$.

Some quantitative conjectures of the population contraction in Spain can be put forward. Population estimates for Aragon and Castile kingdoms in 1300 (Pérez Moreda, 2002) completed with those for Nazri Granada and Navarre, 0.4 and 0.1 million, respectively (Pérez Moreda, 1988) reach a total of 4.5 million for present-day Spain. Pérez Moreda (2002) assumes $0.5 \%$ yearly growth for Spanish population over 1300 1347. We find this assumption on the high side, as qualitative evidence suggests substantial population losses due to bad

\footnotetext{
13 Sobreques Callicó (1970). Vilar (1978, p. 37) defends that Castile was less affected than the Mediterranean coast.

14 Torres Fontes (1981) analysed the development of epidemics in Murcia. For Valencia, cf. Rubio Vela (1979). See also Vaca Alonso (2001).

15 These internal migrations from low to high mortality areas is also predicted by Koyama et al. (2019, p. 27).

16 Castán Lanaspa and Dueñas Carazo (2006, pp. 304-306) maintain that mortality in Navarre was lower and would be around 25\% between 1347 and 1366 . They also cite the same idea defended by Santamaría Arandez (1969) for Majorca and by Guilleré (1984) for Gerona.
} 
harvests and famines in the early 14th century (Valdeón Baruque, 1969, p. 13; 1972b, p. 170; López Alonso, 1978, p. 484; Ladero Quesada, 1981, p. 3; Vaca Lorenzo, 1984, p. 96). Instead, we have accepted Pérez Moreda's growth assumption but excluding years of famine (1301, 1309-11, 1331-1347) for which no population growth was assumed. The resulting figure, 5.0 million, would imply a yearly growth rate of $0.2 \%$ over 1300-1347. As the Black Death had a dramatic impact on the population within a short period of time, 1348-1350, we hypothesise a $25 \%$ contraction between 1347 and 1351, in line with the regional evidence available (Castán Lanaspa, 2020; Furiò, 2013; Pérez Moreda, 1988, 2002). Lastly, the population in the early 15th century was estimated by adding up the population estimate for Christian Spain in 1435, 3.8 million (Pérez Moreda, 2002), and Granada and Navarre's population, 0.3 million, c. 1420 (Pérez Moreda, 1988). Thus, between the eve of the Black Death (1347) the first third of the 15th century, when the effects of the pandemic were fading away, the population would have fallen by $18 \%$, a relatively mild demographic impact.

The contemporary references to the demographic consequences of the Black Death in the rest of Europe suggest that the effect was far more devastating, although measuring the exact percentage of the population that died is a more complicated issue. Some estimates suggest that in certain regions up to $70 \%$ of the population could have died (Heers, 1976, p. 337; Carpentier, 1962, p. 1065). However, as the Spanish experience suggest, the effect was probably asymmetrical and some regions had lower mortality rates than the average (Biraben, 1976, p. 104). Table 1 presents population trends in Europe.
Between 1300 and 1400, population in Europe decreased by around $28 \%$, a fall that highly asymmetrical. At the top, the British Islands were severely hit with loses that ranged from $50 \%$ in Ireland to $30 \%$ in Scotland while, at the bottom, Spain lost around $13 \%$ of its population. We can, therefore, conclude that the severity of the Black Death in Spain was considerably lower than in the rest of the continent, a fact that would also have consequences on other key economic indicators such as average incomes.

\section{Income}

The available literature supports the idea that a period of crisis was underway in Spain before the arrival of the Black Death, and that the economy had started to decline in the second half of the thirteenth century (Vaca Lorenzo, 2001, pp. 43-44; García Sanz 1981, p. 91). This general view defends the existence of Malthusian constraints with relative scarcity of land, increasing use of marginal land, and growing fiscal pressure that triggered famines, making easier the spread and effects of the plague (Valdeón Baruque, 1969; Vaca Lorenzo, 2001, pp. 37-38). Therefore, for these authors the economic decline was endogenous and not consequence of an exogenous shock like the arrival of the Black Death (Blockmans and Dubois, 1997; Berthe, 1984; Vaca Lorenzo, 1990).

Recent studies have gathered empirical evidence to provide new estimates of the evolution of the Spanish economy at macroeconomic level in the very long term. Estimates of GDP per capita for Spain since the end of the thirteenth century are

\section{Table 1}

European Population 1300-1400 (million)

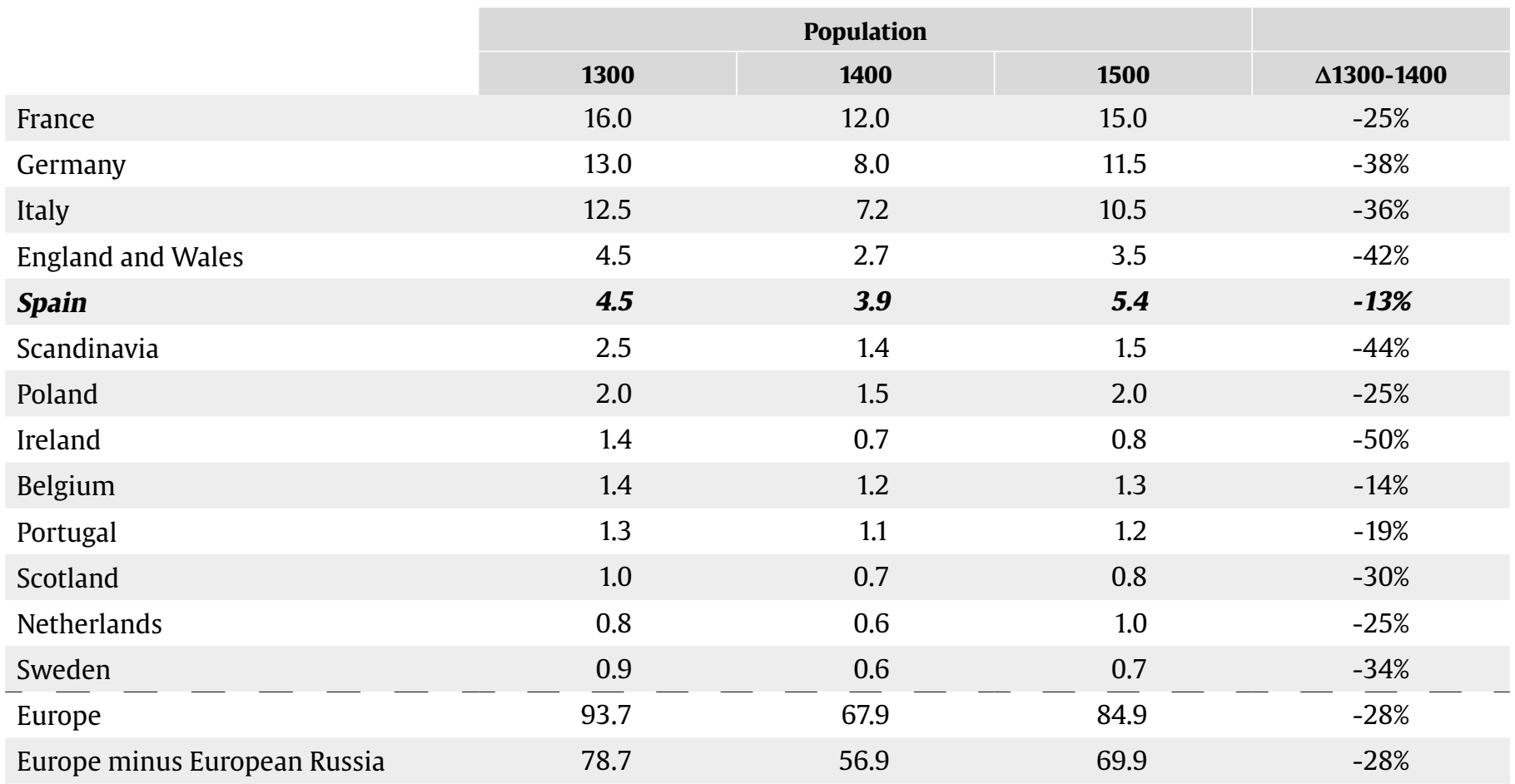

Sources: Malanima (2009, p. 9); Spain, our own estimates based on Pérez Moreda (1988, 2002). See the text; Sweden, Krantz (2017), 1350, 1450, 1520; Italy, Alfani and O'Gráda (2018). 


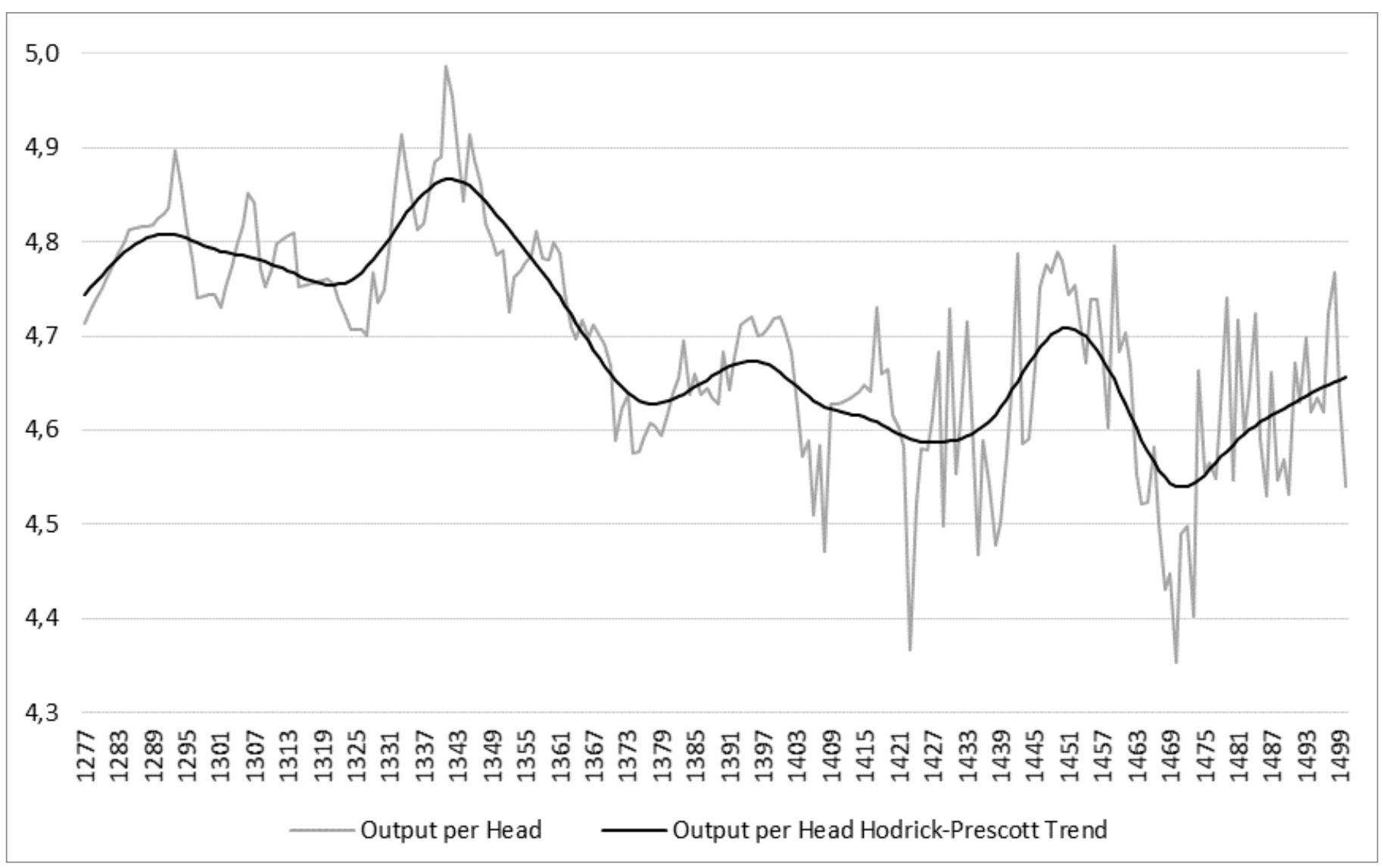

Figure 1. Real GDP per Head: Original Values and Hodrick-Prescott Trend (lambda=1000), 1277-1500 (1490/99=100) (logs).

Source: Prados de la Escosura et al. (2020)

presented in Figure $1^{17}$. The series show the decline during the last decades of the thirteenth century and the first years of the fourteenth that lends support to the qualitative literature, but also a quick recovery during the 1330s. Coinciding with the arrival of the Black Death to Spain we observe that the economic growth suddenly stopped and a sharp decline in per capita incomes took place until the 1370s. The situation persisted in the mid-term and after a period of stagnation, incomes continued to decline reaching the lowest levels in the early fifteenth century, followed, then, by a period of recovery, punctuated by a contraction in the late 1460 s-early 1470 s, during a period of civil war and social unrest, that did not re-gained pre-Plague income levels. In fact, the income per head achieved before the Black Death would not be overcome until the early nineteenth century (Prados de la Escosura et al., 2020).

How do these results compare to the performance of other European economies? Figure 2 compares the GDP per head for Spain, with those for France, Britain, the Netherlands, Sweden, and Italy (Centre-North). The most striking difference is the sudden recovery experienced in most countries, but Spain, with a considerable rise in income per head across the board and particularly intense in Britain. In these cases the behaviour of the economy goes in line with the expected results in a society constrained by Malthusian pressures. When those constrains are eliminated through a reduction of population, the incomes for

\footnotetext{
${ }^{17}$ For a detailed description of the estimation, methodology and sources, see Prados de la Escosura et al. (2020)
}

those who survived the pandemic increased. Some authors even affirm that the Black Death allowed a change of demographic regime in Europe that put the foundations for the Great Divergence (Broadberry, 2013; de Pleijt and van Zanden, 2016). Others pointed out to its importance also within Europe, as it triggered the beginning of the Little Divergence (Pamuk, 2007; Koyama et al., 2020). In the Spanish case, the decades that followed the Black Death were also affected by other political and economic factors, Prados de la Escosura and Rodríguez-Caballero (2020) show that the structural break associated to the Plague led Spain to falling behind the most dynamic economies in northern Europe.

Why were Spain and, to some extent, Sweden different from the other European economies? A first answer can be associated to the fact that the demographic crisis in Spain was considerably milder than that experienced in the rest of Europe. If that was the case, the benefits in terms of increasing average incomes for those who survived would be lower as labour would be more abundant. This would explain the smaller increase in the case of France relative to that of Britain, where the crisis was harder, but not a decline in absolute terms like the one that we observe in Spain. It is our hypothesis that the main reason behind the collapse of income per head in Spain is that its economy was not Malthusian at all, and that, therefore, a reduction of population did not translate in an improvement in the incomes of those who survived. The fact that GDP per head fell immediately after the plague supports this view. As we will explain in detail in the following lines, the Spanish economy before the arrival of the Black Death had reached a delicate equilibrium that was highly vulnerable to changes in the supply of labour. 


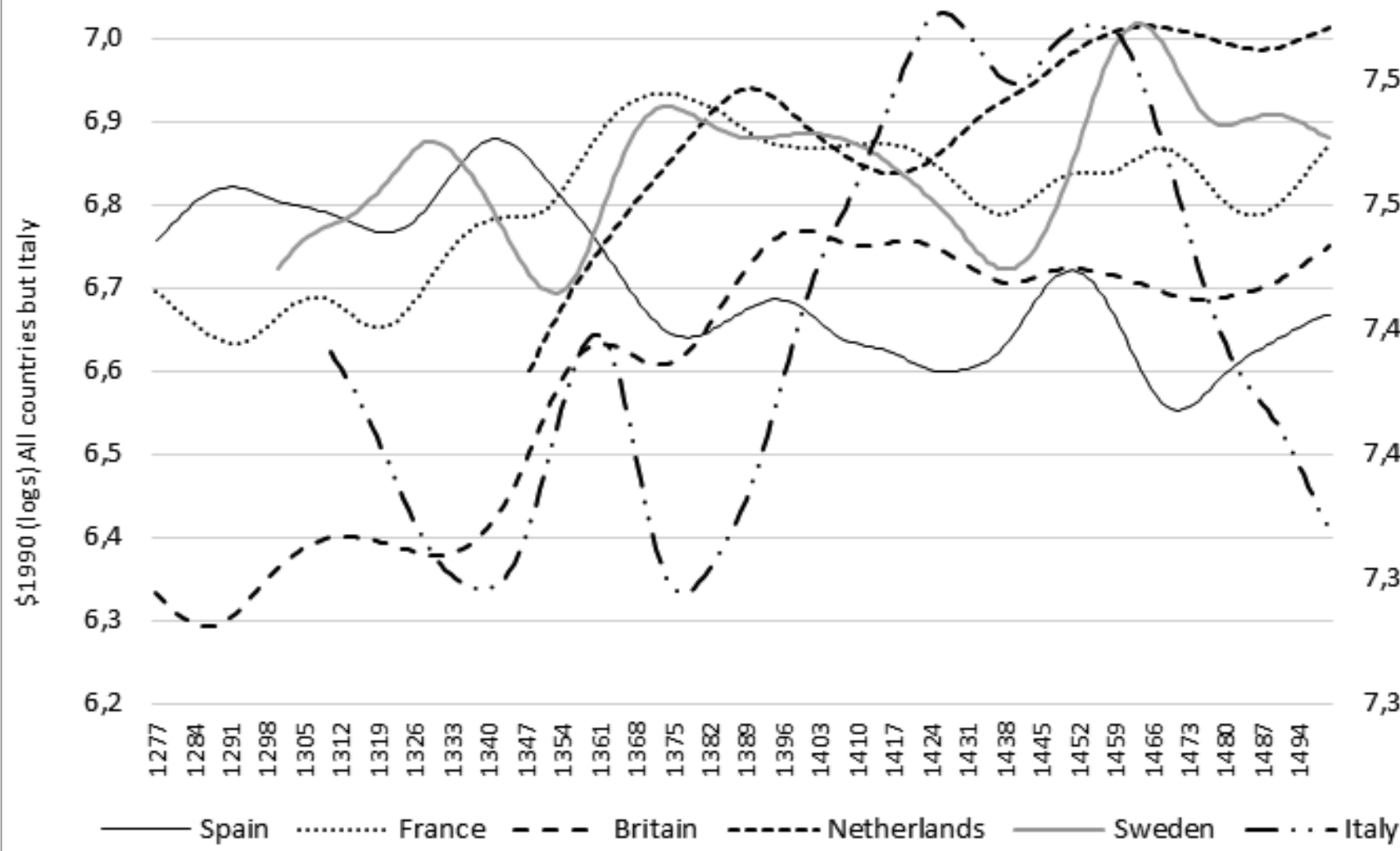

Figure 2. Hodrick-Prescott Trends in Real GDP per Head in European countries, 1277-1500 (Geary-Khamis \$1990) (Italy right axis) (logs).

Source: Prados de la Escosura et al. (2020), Broadberry et al. (2015), Krantz (2017), Malanima (2011), Ridolfi and Nuvolari (2020), and van Zanden and van Leewen (2012).

Note: To facilitate the comparison, Italy's higher GDP per head is represented on the right hand scale.

But was this just a short term event? We can check to what extend the Spanish economy fits into a Malthusian framework in the long run comparing the evolution of population and income per head over time. If Spain was an economy constrained by Malthusian forces, incomes would increase with decreases of population and vice versa.

As figure 3 shows, the relationship between population and income per head in Spain appears mostly positive, revealing that overpopulation did not seem to have been an issue limiting improvements in average incomes. As already suggested in the literature (MacKay, 1977; Valdeón Baruque, 1984), the existence of a frontier economy, resource abundant, in preindustrial Spain provides an answer. Frontier economies are defined by an abundance of natural resources (especially land) and scarcity of labour, where the economy organises itself around the exploitation of the abundant input. The frontier in Spain was literal, and was settled by the Reconquista, where the instability of the borders and the high land-labour ratio encouraged the development of a pastoral system intensive in the use of land and scarce in the use of labour (MacKay, 1977). The territories that were incorporated to the Christian kingdoms (mainly Castile) from the eleventh century served to relieve any potential demographic pressure of the territories in the north (Rodriguez, 2011). The increase in the land/peasant ratio could explain the rise of agrarian productivity in a process characterised by extensive growth cultivating more land, where the connection between the agrarian producers and the urban consumer was key (Oliva Herrer, 2007, p. 306). Therefore, far from living at subsistence levels, peasants of pre-Black Death Spain were part of a highly integrated economy where the commercial links between the cities and the countryside were very intense.

Given low population density and high land-labour ratios, demographic expansion appears to have had increasing economic returns in a largely pastoral society that was led by urban nuclei and connected to international trade networks. The frontier economy helps to explain why the Black Death had devastating economic effects despite its comparatively milder demographic impact, as the Plague destroyed a pre-existing fragile equilibrium (Álvarez-Nogal and Prados de la Escosura, 2013).

After the worst effects of the Black Death had passed, the economy quickly reorganised and accelerated the processes that had started decades before the arrival of the plague (Furió, 2013, p. 52). From the late fourteenth century onwards, the commercial networks were re-established and the primary sector found new opportunities in the production of materials demanded by a rising manufacturing industry and a recovered urban demand. Castilians exported wool and gold and imported expensive textiles, jewellery, and all kinds of luxury goods in exchange making possible the creation of a national and international trade network that was maintained through a network of fairs and a vibrant urban economy (Álvarez-Nogal and Prados de la Escosura, 2013). 


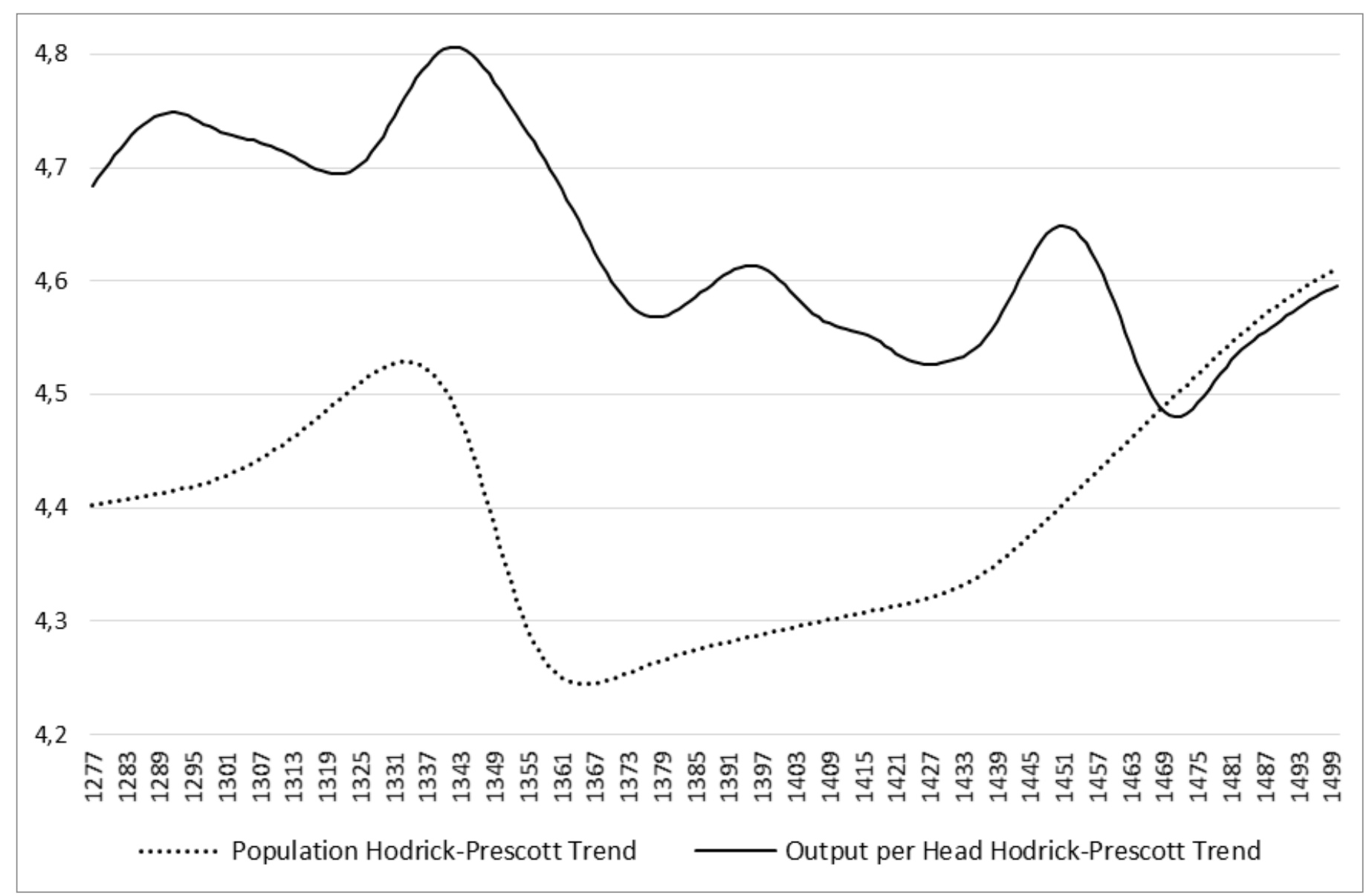

Figure 3. Hodrick-Prescott Trends in Spain's GDP per Head and Population, 1277-1500 (1490/99=100) (logs).

Source: Prados de la Escosura et al. (2020).

\section{Table 2}

Urbanisation rates and population density in selected European countries

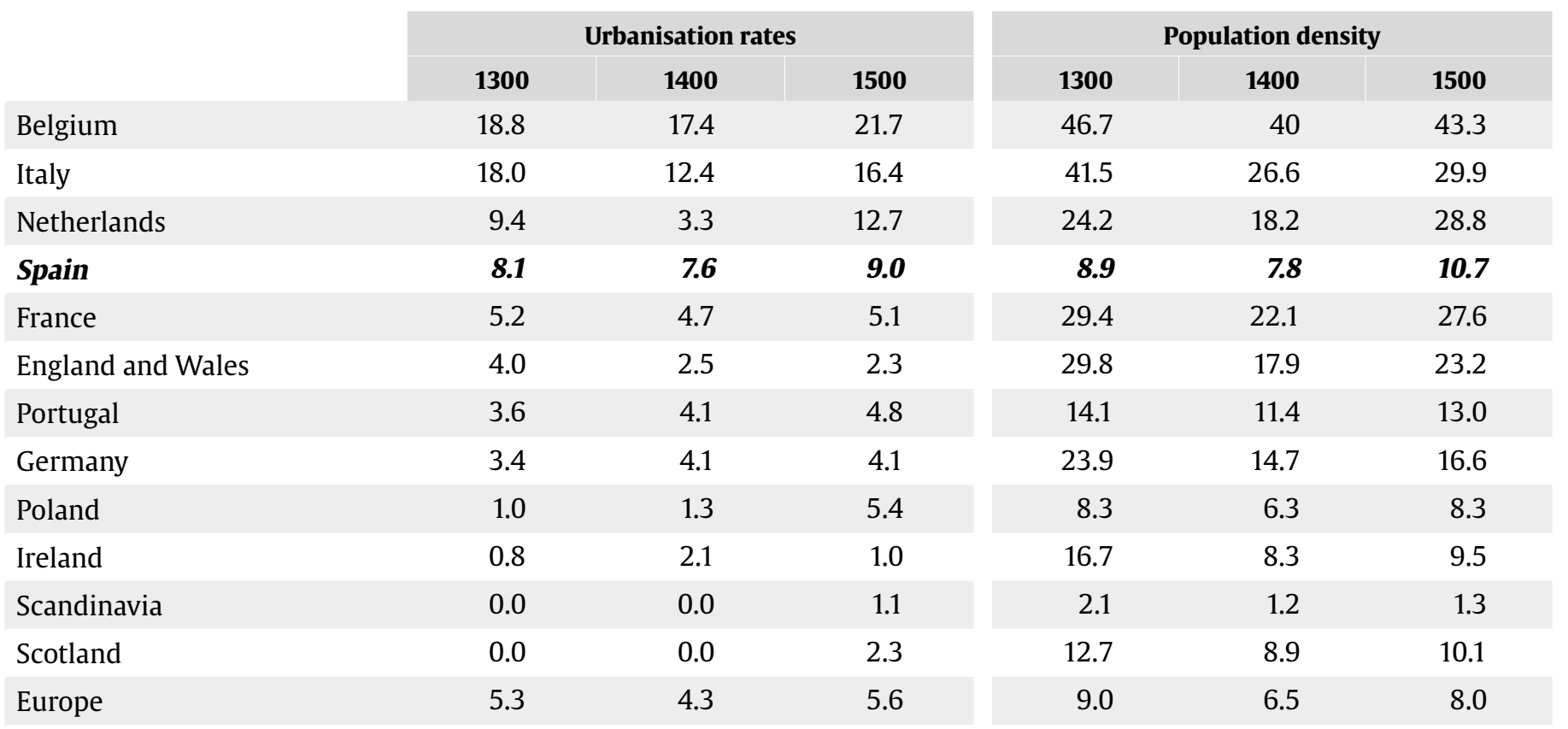

Sources: Malanima (2009, pp. 16, 246), for Spain Prados de la Escosura et al. (2020) 
Table 2 supports this description of the Spanish economy, where we can observe that Spain had one of the lowest population densities of the continent and one of the highest urbanisation rates ${ }^{18}$. This means that the percentage of the population employed in the rural economy was considerably lower and the amount of land available per worker much higher than in the rest of Europe. This also explains why although the demographic impact of the plague was milder in Spain than anywhere else in Europe, it hit harder an economy organised around a fragile system that was very sensitive to changes in the scarce resource, labour. Labour in Spain showed increasing returns to scale as output grew more proportionally than workforce. When the disease killed a large proportion of the population and, hence, the labour force, the economy lost ground as we observe in the fall in production.

If in more densely populated countries rural labour could easily be replaced by an oversupply of population, in Spain the loss of labour produced the abandonment of large areas and the collapse of the rural economy and the urban links through trade associated to it ${ }^{19}$. When we think of a rural economy and rural population we should not think only in terms of a single economic activity, namely, agriculture, but also in manufacture activities and services provided. Many of these sectors suffered with the plague leaving isolated many urban areas when commercial networks disappeared deeply affecting urban economies. Peasants who previously enjoyed the benefits of having access to a large urban market had to retreat to strategies closer to subsistence economies (Furió, 2013, p. 54). Koyama et al. (2019, p. 25) argued that after hit by the plague, cities recovered from migrants that arrived from rural areas. The fact that Spanish cities recovered more slowly in the short term (ibid., p. 20) suggests that the Spanish countryside could not provide labour for urban areas as quick as other countries did.

\section{Inequality}

A pandemic such as the Black Death also affected income distribution. Lack of empirical evidence has led economic historians to rely on indirect estimates of economic inequality. One of them is the ratio between nominal land rent and nominal wage rates, understanding that land is less evenly distributed than raw labour, so the former would capture the returns of the relatively wealthy and the latter of those less privileged.

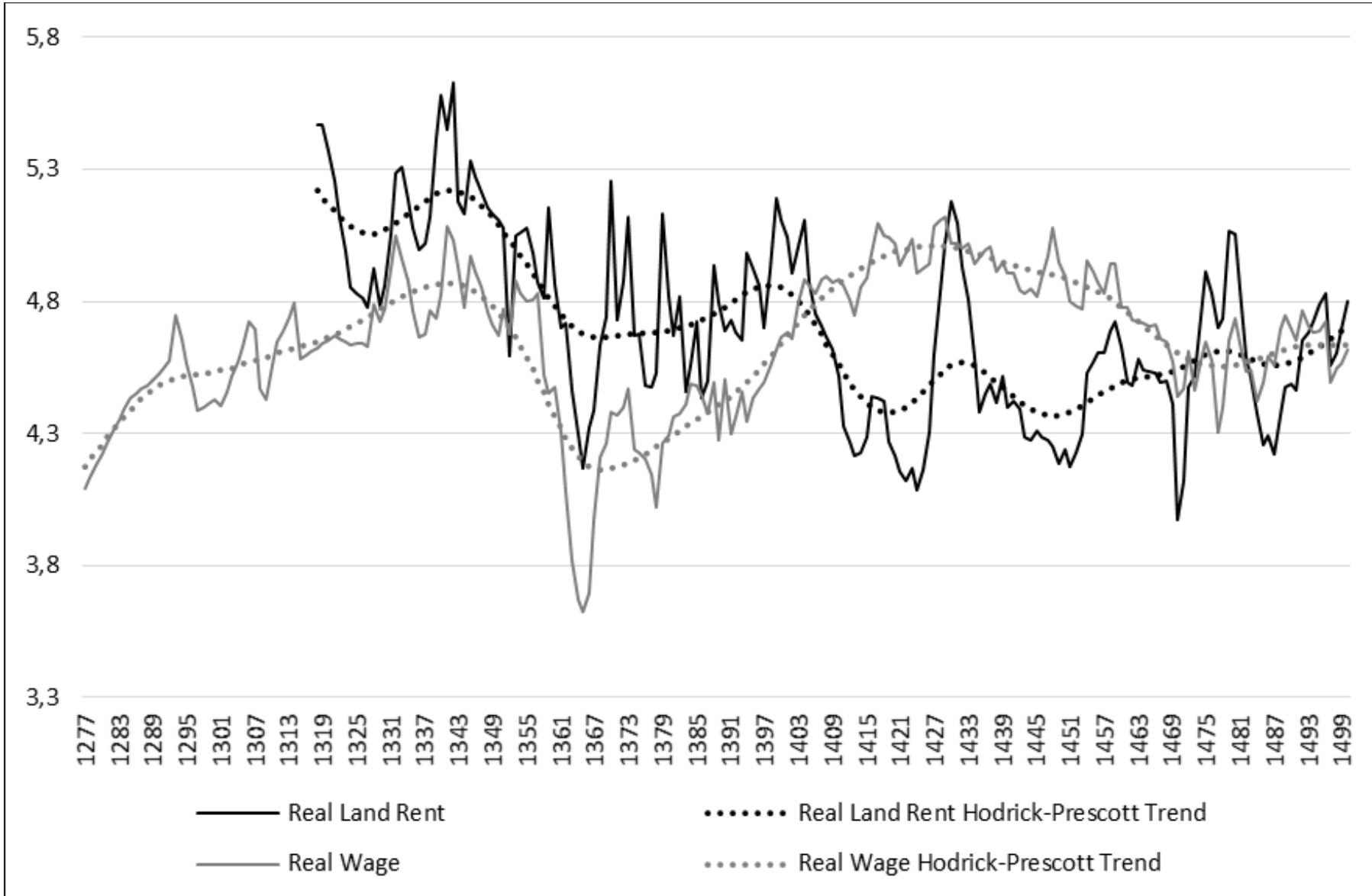

Figure 4. Real Wages and Land Rent, 1277-1500 (1490/99=100) (Hodrick-Prescott filter (lambda=1000) (logs).

Source: Prados de la Escosura et al. (2020).

${ }^{18}$ The urbanisation rates for Spain are adjusted, excluding those locations that would be considered urban for their size but not for the character of their economy (agro-towns).

${ }^{19}$ Kelly (2001) found similar effects in the case of Ireland. 


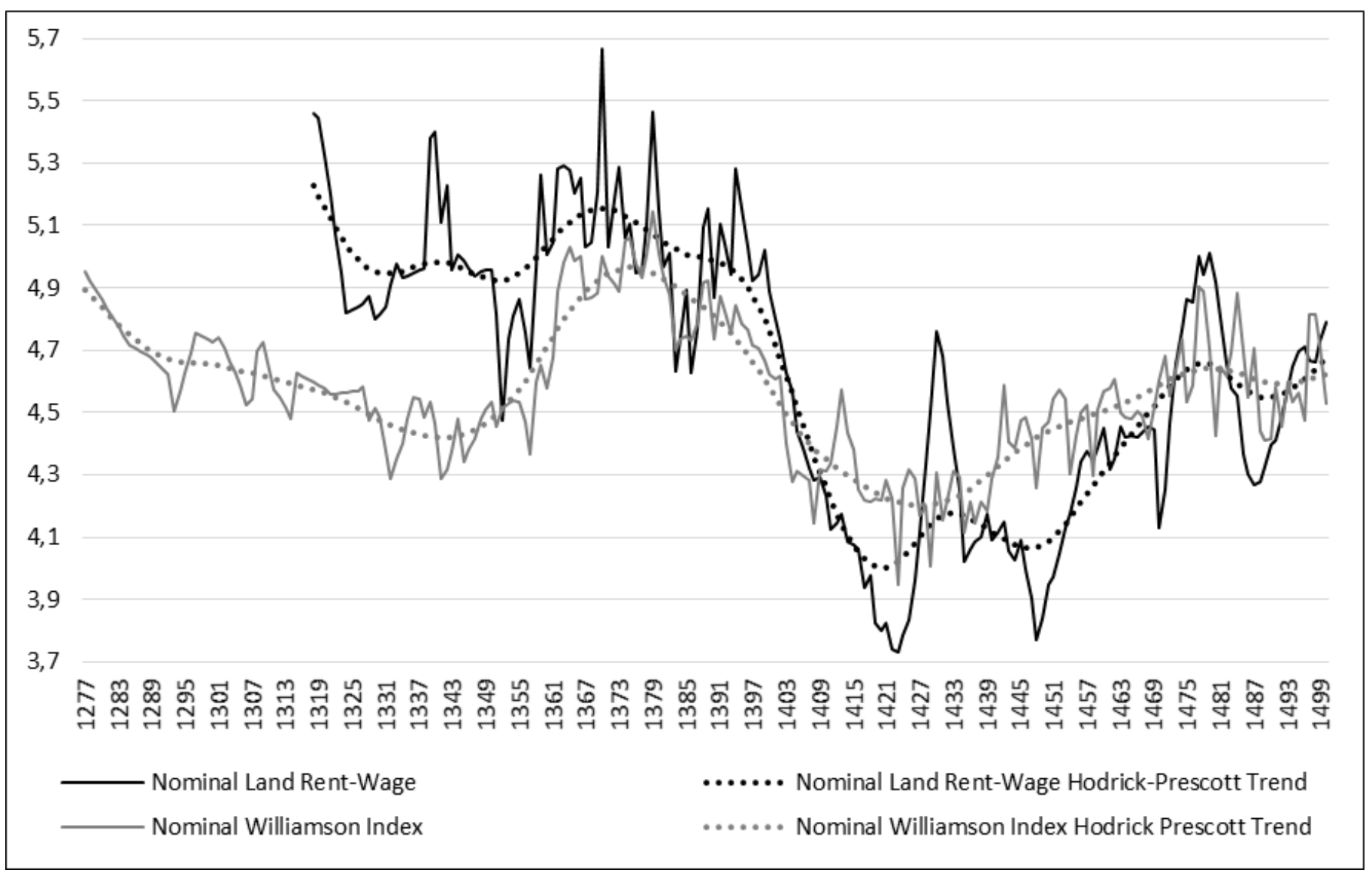

Figure 4. Nominal Williamson Index and Land Rent-Wage Ratio, 1277-1500 (1490/99=100) (Hodrick-Prescott filter (lambda=1000) (logs).

Source: Prados de la Escosura et al. (2020).

A second option is the Williamson index, expressed as the ratio between nominal output per capita and nominal wage rates. The idea behind the index is that the numerator, output per head, captures the returns to all factors of production while the denominator represents the returns to labour. Assuming that the bottom part of the distribution obtains their incomes from wages, the Williamson Index (WI) compares the returns of the average to those of the bottom of the distribution. An increase in WI would mean that the returns obtained by the average increase relative to those at the bottom and, hence, that inequality rises ${ }^{20}$.

Figure 4 shows the evolution of real land rents and real wage rates in Spain between 1277 and 1500. The plague produced a sharp decline of both series, although the decrease was more intense in the case of wages. The combination of both variables implies that inequality rose immediately after the outbreak, a situation that we can confirm in Figure 5 where we present the evolution of the land rent/real wages ratio and the Williamson index in nominal terms to avoid potential distortions introduced by different deflators. Furthermore, inequality also rose between landowners, as growing differences between larger and smaller peasants in the Crown of Aragon show (Furió, 2013, p. 44)

\footnotetext{
${ }^{20}$ The Williamson Index is therefore defined as WI = PIB/Wage and the
} Rent/Wage ratio as Rent/Wage
The years following the Black Death in Spain witnessed an increase in inequality, a finding at odds with the experience in other parts of Europe, where the effects of the Plague produced an intense reduction in economic inequality (Scheidel, 2017), although inequality fell sharply again in Spain between the late 1370 s and the 1420 s and remained at lower levels for the rest of the 15th century. In the case of Italy, Alfani (2015) found that in Piedmont, between 1300 and 1800, the Black Death was the only event that produced a decrease in inequality, a fall that also took place in Tuscany (Alfani and Ammannati, 2017). Similar trends were also observed in Northern Italy and Southern France. Societies became more egalitarian because real wages increased rapidly, a process that also reduced wealth inequality through a change in the relative prices between wages and capital. (Alfani and Murphy, 2017, p. 333-334).

Therefore, the evolution of wages seems to be a key factor behind the differences between Spain and Europe in the changes in economic inequality. Did they behave so differently in Spain immediately after the plague? Nominal wages did increase in Spain after the Black Death. In Murcia master bricklayers who earned eight maravedis in the 1390s, reached eighteen in the early fifteenth century. Wages for unskilled rural workers more than doubled in line with similar increases for other unskilled professions (Falcón Pérez, 1985; Menjot, 1993). Nominal wages also increased in Aragon before and after the arrival of the plague for men and women in almost every sector, for workers paid in cash but also to those paid in kind (Campo Gutiérrez, 2006, pp. 110-111). There were how- 
ever some exceptions, like maids who suffered a deterioration in their wages in Zaragoza ${ }^{21}$. Contrary to what was observed in other regions like Tuscany, the length of their contracts increased from 1365 onwards, from around one year at the beginning of the fourteenth century to up to six years in the middle $^{22}$. Therefore, in the short term the general trends shows that decrease of real wages that we observe was not consequence of decreasing nominal wages, but of a rapid increase in prices that did not fall in Spain as rapidly as they did in other parts of Europe. The rapid inflation was also fostered by the devaluations that took place during the fourteenth century (Furió, 2013, p. 48).

In Castile price levels multiplied by a factor of four or five between 1345 and 1390 (Ladero Quesada, 1981, p. 10) ${ }^{23}$. While during the first third of the fourteenth century one fanega of wheat cost around 5 maravedis, the price almost doubled at the end of the century (Valdeón Baruque, 1989, p. 232). political events influenced inflation, like the war between Castile and Aragon and the presence of a Castilian army in Murcia between 1364 and 1365. Rice, wheat and barley was diverted from the market to maintain the army producing price increases that doubled or trebled (Martínez Carrillo, 1985, pp. 85, 93). However, the plague itself also had an effect like the wave of 1379-80 that increased prices in the autumn of 1380 and spring of 1381 (ibid., p. 111). Inflation was systematic during the whole reign of Juan I (1379-1390) and affected also to other staple products like meat (ibid., p. 106).

Similar trends were observed in Aragon, where in the lands controlled by the knights Hospitaller of Saint John of Jerusalem the population fall produced social unrest and a sudden increase in prices (Luttrell, 1966, pp. 499, 507). In Catalonia Vilar suggested that the increase of prices was one of the few benefits that lords obtained at the time, an inflationary process also observed in detailed studies in around the Plana de Vich and in Mallorca ${ }^{24}$. Coastland economies did not escape from rising prices, and even fresh or salted fish in Valencia saw increases in 1350 (Rubio Vela, 1979, pp. 63-64). There are signs suggesting that real wages started to decline at the end of the fourteenth century before similar trends were found in Europe, a process that appeared before in Castile than in Aragon. The inflation that followed the Black Death quickly eroded the gains derived from increasing nominal wages (Furió, 2013, p. 42).

The European experience on prices was in general very different. The immediate effect of the plague in rural areas was the reduction in cultivated land (Vaca Lorenzo, 2001, p. 29). England, Norway and Sweden recorded the abandonment of farms and a reduction of rents and agrarian prices (Schreiner, 1948). Grain prices show an intense decrease up to 1460 that in cases like England or Belgium continued until 1500 and that was also affected a relatively high level of economic integration of the European market (Bois, 2001: Abel, 1973; Pamuk,

\footnotetext{
${ }^{21}$ The length of contracts is an indicator of the bargaining power of the domestic servant to establish his remuneration.

${ }^{22}$ Campo Gutierrez (2006, p. 101) shows how contracts in Zaragoza increased during the fourteen century. In other aspects the contracts in Spain were similar to those in Europe (Iradiel, 1986, p. 251).

${ }^{23}$ Sobrequés Callicó (1970, p. 86) argues in favour of an increase but does not provide numbers.

${ }^{24}$ For Plana de Vich see Pladevall (1962), for Majorca Sobrequés Callicó (1970, p. 84).
}

2007, p. 295). The decrease of grain prices is explained by an oversupply caused by the sudden demographic collapse and a relatively well integrated European grain market that by the end of the fourteenth century also reached large parts of Spain (Lamprecht, 1885-1886; Furió, 2013, p. 50). The changes in the velocity of money in circulation could have also played a role (Robinson, 1959).

Combined with falling prices, the scarcity of labour in Europe increased nominal wages and gave way to what has been defined by many researchers as the golden age of real wages (Bois, 2001, p. 98). Some authors argue that the main responsible of this new cycle was the arrival of the plague in 1347 (Voigtländer and Voth, 2013; Brown and Hopkins, 1981; Alfani, 2020). This process first started in the countryside and moved soon to the rest of the economy ${ }^{25}$. In the bishopric of Winchester wages in grain doubled between 1300 and 1379 (Vaca Lorenzo, 2001, p. 29). Braid (2009) on the other hand suggested that gains in real wages in England after the Black Death were, if any, very limited. Wages doubled in Paris between 1349 and 1370 and in Rouen a worker's salary paid in grain practically trebled between 1300 and 1450 (Bois, 1986). The trends were common in all of Europe and the Middle East where nominal wages rose coinciding with the demographic and monetary crises of the time (1348-1360, 1418-1422) (Bois, 2001; Pamuk, 2007, p. 297). Workers not only received more for their work, they also improved their working conditions with more freedom to choose and decide when to stop working (Dyer, 1991, p. 291). In this case it was the rich who lost more, not being able to take advantage of the favourable conditions of the market (Koenigsberger, 1991, p. 262).

Moving to the upper part of the income distribution, lords were affected by increasing expenditures, as the rise in nominal wages produced by the fall in population and by falling rents. This situation affected all the privileged classes including the nobility, church, monasteries and also the Crown. Rents fell by one third in the bishopric of Oviedo, and the monastery of Sahagún suffered even higher loses of around $50 \%$ between 1338 and 1358 (Vaca Lorenzo, 1983). Similar figures are in the payments that the Crown obtained from collectors. The response of the nobility was immediate, trying to control the loss of revenues that they obtained from rents, conditioning their support to Enrique II de Trastámara to the acquisition of privileges that compensated the decrease in revenues (Valdeón Baruque, 1966). The creation of the majorat and the prohibition of emphyteusis or the censo perpetuo are seen as examples of the royal response to those requests (Clavero, 1974). As in other regions of Europe, peasants paid most of the cost of this reaction, especially when the Crown allowed the direct control of substantial amounts of the territory by the nobility (Martín Cea, 1986). After the plague, seigniorial pressure on peasants grew in Castile and many lords claimed to abolish behetrías, namely, old municipalities of free peasants with the right to choose their lord (Ferrari Núñez, 1958; Martínez Díaz, 1981; Estepa Díez, 2003). This implied not only the loss of privileges and traditions that those areas previously enjoyed, but also the creation of new taxes and an important reduction of municipal independence that many localities had enjoyed

\footnotetext{
${ }^{25}$ Following the Malthusian theory, real wages decreased during the whole thirteenth century, but the trend changed in the mid fourteenth century. Research from Brown and Hopkins (1981).
} 
from the Reconquista (Pretel Marín, 1982, p. 153). Therefore, in Castile higher taxes and less freedom was the price that the peasantry had to pay in order to compensate the losses of the privileged classes. We find similar movements in Aragon and Catalonia, where landlords preferred lowering their rents that in some cases halved (Luttrell, 1966, p. 503). The decrease also affected urban areas, where houses' rents fell. Taxes on the other hand did not decrease globally, because although some did other grew with few exceptions like those collected in customs (Kuchle, 1969, p. 68).

The privileged classes also worked hard to reduce the rising costs derived from increasing nominal wages. To limit salaries in Castile, Pedro I accepted to top up wages paid to rural workers in 1351, but the law failed and many lords decided to abandon the cultivation of their lands (Sanz Fuentes, 1987, p. 1565; Vaca Lorenzo, 2001, p. 45). A similar process of reducing the extension of cultivated land happened in Orense as a consequence of higher rural wages (Duro Peña, pp. 68-69). Similar laws were created in other regions of Spain like Aragon, Navarre, Valencia or Toro ${ }^{26}$. In Aragon the king kept control of the wages paid to those occupying a public office (Kuchler, 1969, p. 67). Few of these were successful and in cases like Zaragoza they were abolished two years later after damaging the guilds (Sobrequés Callicó, 1970, p. 73). There were also interventions in Europe to moderate the increase of wages including efforts to top up salaries (Cohn, 2007). England and France introduced legislation that forced people to work and controlled their wages, although their effects were also limited (Bois, 2001, p. 96).

Therefore, the reaction of the rich and powerful in Spain was not as successful as expected, and it was far softer than in other areas like Eastern Europe. The low population density and high levels of competition between lords explain why in the Spanish case they limited the intensity of their response to avoid losing vassals. An example is the reduction in taxes for the organisation of fairs during the fifteenth century, where different lords competed against each other as the fairs of Medina del Campo, Villalón and Medina de Rioseco show in the centre of Castile. The role of the main cities, those with delegates in the Cortes, was also relevant to limit the reaction of the nobility. Urbanisation levels in Castile were traditionally high and therefore their power was key to counterbalance the interests of the lords. They had their own laws, levied their own taxes, and had the support of the monarchy. Their presence in the Cortes gave them the visibility and influence to antagonise the actions of the privileged classes.

To sum up, the milder demographic consequences of the Black Death in Spain meant that nominal wages increased less rapidly than they did it in other parts of Europe, where the behaviour of prices also allowed larger gains in real terms for the lowest social classes, explaining the sharp reduction in inequality that did not take place in Spain immediately after the Plague. At the same time, although the attempts by the landowners to sustain rents generally failed, they did not decrease as much as real wages did. The consequence was a growing gap between proprietors' and labour gains that explains the rise in inequality that we observe in the case of Spain.

\footnotetext{
${ }^{26}$ Navarre Monteano (2001, p. 117), for Valencia Rubio Vela (1979, p. 62), for Toro Martín Cea (1986, p. 131).
}

\section{Long term consequences}

The direct effects of the Black Death in Spain established the foundations for its growth during the following centuries. The short term consequences of the plague were negative, with the destruction of a fragile organisation based in a frontier economy. However, in the long run the demographic recovery that followed reinforced the system with increasing trade, urbanisation and a more intense specialisation in high value added production.

The general view of the Black Death primarily affecting urban economies has been recently disputed ${ }^{27}$. While contemporary advice counselled escaping when the plague arrived, where to go was not such an easy decision. Short-term food shortages were harder in cities, but long term coverage from hunger was probably better found in urban centres that offered public goods, security and protection (Laredo Quesada, 1981, p. 4). The growing number of depopulated rural areas supports the idea of increasing migration from the countryside to the cities (Valdeón Baruque, 1972a, p. 88). Koyama et al. (2019, p. 29) support this idea and explain how most of the recovery of urban population came from rural migration. We have several examples of cities that were able to resist and even increased their populations after the pandemic. In Burgos there were no signs of population decline during the outbreak (Casado Alonso, 2009). Valencia raised its population even after the waves that followed the plague of 1348 (Rubio Vela, 1987, p. 109). A similar situation took place in Jaen, and in cities like Córdoba the number of rented houses increased because new neighbours occupied the places of those who passed away (Rodríguez Molina, 1975, p. 31). The higher mortality in rural areas of Majorca compared to the city can only be explained by a transfer of population from the countryside (Santamaría Arández, 1969, p. 120). In Vic there was an intense movement of people from the surrounding areas to the city thanks to the fiscal advantages that its authorities granted to the migrants, and for the security that it offered (Pladevall, 1962; Cuvillier, 1969). Other parts of Iberia showed similar trends like Portugal, where the Black Death marked the beginning of a growing urban economy (de Oliveira Ramos, 1963, pp. 220-229).

Therefore, the high levels of urbanisation that Spain presented did not suffer much (Mitre Fernández and Granda Gallego, 1982, p. 832, and Table 2). Aragon and Catalonia were less urbanised than Castile, partly consequence of the way the Reconquista was carried out (Zulaica Palacios, 1995, p. 132). From the mid eleventh century up to the battle of Las Navas de Tolosa an urban network is created in Castile, followed by a second wave that lasts until the arrival of the Black Death (Ladero Quesada, 1986, p. 573).

The reinforcement of the urban economy in Spain was also possible thanks to a deeper specialisation in the countryside, recovering many of the economic strategies that the disease had stopped or destroyed right after 1348. The rural world reorganised its production, and in those areas where land was abundant relative to labour the production was reoriented

\footnotetext{
${ }^{27}$ There are no reasons to believe that it affected more to those regions more populated or differences between rural and urban areas (Monteano, 2001, p. 107). Romano and Tenenti (1977, p. 6) follow the same argument. For Cordoba see Collantes de Terán Sánchez (1980, p. 78).
} 
towards a pastoral economy (Borrero Fernández, 2007, p. 53). In this process, the frontier economy based on wool production intensified following the depopulation of the countryside and the reduction of arable lands not needed to feed a smaller population. Peasants also benefited from an increasing demand from artisans and workers in the growing urban economies (Furió, 2013, p. 54). Cheaper land attracted urban investors but also the high nobility, ecclesiastical lords and powerful monasteries. Regions like Murcia where the plague hit harder lived a more profound transformation including new legislation protecting cattle breeders. From the mid fifteenth century, the recovery of the Castilian countryside was generalised (Oliva Herrer, 2007, p. 297). Although the process also took place in Aragon, it was not as intense as in Castile ${ }^{28}$. The former was encouraged by the demand from northern Italy, while the later benefited from the diversion of Flanders demand from England (Ibarra Téllez, 2007, p. 133). Castilian merchants from Burgos expanded their networks through France, England and the Low Countries. Using Bilbao as their main port for exports, after 1390 they established commercial colonies from Lisbon to Antwer p. Burgos became the main insurance centre in the Iberian Peninsula and capital profits were invested heavily in the Castilian countryside and wool production (Casado Alonso, 1987). The growth in internal trade and the rapid development of the commercial networks reduced transaction costs and favoured regional specialisation in a process similar to the one described by Epstein (1994).

The international demand of high-priced merino wool increased productivity in the rural economy. At the same time trade networks connecting the countryside with the cities and these with the international markets expanded, reaching a more favourable position in Castile (Igual Luis, 2007, p. 210$212)^{29}$. The development was not circumscribed only to the production of raw wool, and the production of mulberry trees and hemp whose production was closely tied to the manufacturing sector also increased (Furió, 2013, p. 54). Spillovers also appeared in the tertiary sector related to trade and in the secondary sector with the rise of the textile industry. Therefore, if the short term effects of the Black Death in Spain were negative, by the 1470 s the economy was already recovering. In the long term the most important effect of the plague was the reinforcement of an economic model based on an efficient and complex rural sector, not just on peasants living at subsistence levels struggling with low productivity crops.

\section{Conclusion}

The arrival of the Black Death to Europe produced the worst demographic crisis in recorded human history. However, within the European context not all the countries suffered its effects in the same way. The Spanish case became an exception to the European rule, with a relatively mild population loss but an intense decrease in incomes per head. Also contrary to the

\footnotetext{
${ }^{28}$ Koyama et al. (2019, p. 25) suggest that the fact that cities recovered population faster than the use of land imply that peasants in rural areas after the Black Death could have been substituted by livestock.

${ }^{29}$ We should also consider that the process was not symmetrical, and that regions like Catalonia lost access to international markets, partially consequence of the increasing competition from other regions of Spain like Castile (Feliú, 2004).
}

experience in Europe, inequality in Spain increased after the Plague and the differences between labour and capital gains grew in the years that followed the outbreak, when real wages decreased more rapidly than did land rents.

As consequence of the impact of the plague, Spain fell behind the most dynamic economies in Europe for a century, but was able to reorganise its economy and catch up again from the mid fifteenth to the late sixteenth century (Prados de la Escosura and Rodríguez-Caballero, 2020). Therefore, although we observe a period of divergence with northern Europe immediately after the plague, the Spanish economy was able to recover quickly in a process of catching up that lasted until the beginning of the seventeenth century. It was only then when we observe Spain falling behind the main economies of the continent (Prados de la Escosura et al., 2020). In the long term, the Black Death reinforced a system of frontier economy based in the production of high value agrarian products, where the rural sector was well connected to a vibrant urban economy, and from it to the rest of Europe. Far from falling behind, the growth that Spain experienced in the following century would led her to a privileged position at the Age of the Discoveries.

\section{Acknowledgments}

We would like to thank the editors, three anonymous referees for their comments and suggestions, and the invaluable advice of Vicente Pérez Moreda. Prados de la Escosura acknowledges research support from Fundación Rafael del Pino.

\section{Bibliography}

Abel, W., 1967. Spopolamento dei villaggi e caduta dei prezzi in Europa nel basso Medioevo. In Romani, R. (ed.). I prezzi in Europa dal XIII secolo a oggi. Einaudi, Torino.

Abel, W., 1973. Crises agraires en Europe (XIIIe- XXe). Flammarion, Paris.

Alfani, G., 2015. Economic Inequality in Northwestern Italy. Journal of Economic History, 75 (4), 1058-1096.

Alfani, G., 2020. Pandemics and asymmetric shocks (No. 478). Competitive Advantage in the Global Economy (CAGE).

Alfani, G. and Ammannati, F., 2017. Long-term trends in economic inequality. Economic History Review, 70 (4), 1072-1102.

Alfani, G. and Murphy, T., 2017. Plague and lethal epidemics in the Pre-Industrial World. Journal of Economic History, 77 (1), 314-343.

Alfani, G. and O'Gráda, C., 2018. The timing and causes of famines in Europe. Nature Sustainability, 1 (6), 283-288.

Álvarez Nogal, C. and Prados de la Escosura, L., 2013. The rise and fall of Spain (1270-1850). Economic History Review, 66 (1), 1-37.

Amasuno Sárraga, M. V., 1994. Cronología de la peste en la corona de Castilla durante la segunda mitad del siglo xiv. Studia Historica. Historia Medieval, $12,25-52$.

Amasuno, M. V., 1996. La peste en la Corona de Castilla durante la segunda mitad del siglo xIV (No. 12). Junta de Castilla y León, Consejería de Educación y Cultura, Salamanca.

Arrizabalaga, J., 1991. La peste negra de 1348. Dynamis, 11, 73-118.

Berthe, M., 1984. Famines et épidémies dans les campaganes navarraises à la fin du Moyen Age, Paris.

Biraben, J. N., 1976. Les hommes et la peste en France et dans les pays européens et méditerranéens, Mouton \& Co., Paris-La Haya.

Blockmans, W. and Dubois, H., 1997. Le temps des crises (XTVe et XVe siècles) In: Bardet, J.P. and Dupâquier, J. (eds.). Histoire des populations de l'Europe. Vol. I. Fayard, Paris, pp. 185-217.

Bois, G., 1986. La crisi del feudalisme a Europa a la fi de l`Edat Mitjana, Societat Catalana de d'Estudis Històrics, Barcelona.

Bois, G., 2001. La gran depresión medieval: siglos xIv-xv. Publicacions de la Universitat de València, Valencia.

Borrero Fernández, M., 2007. El mundo rural y la crisis del siglo xIv. Edad Media, $8,37-58$. 
Bourin, M., Carocci, S., Menant, F., and Figueras, L. T., 2011. Les campagnes de la Méditerranée occidentale autour de 1300. Annales. Histoire, Sciences Sociales, 66 (3), 663-704.

Braid, R., 2009. Economic Behaviour, Markets, and Crisis. In: Economic and Biological Interactions in Pre-Industrial Europe from the $13^{\text {th }}$ to the $18^{\text {th }}$ Centuries, Proceedings of the XLI Settimana di Studi, Prato: Istituto Internazionale di Storia Economica F. Datini

Broadberry, S. N., Campbell, B. M. S., Klein, A., Overton, M. and Van Leeuwen, B., 2015. British economic growth, 1270-1870. Cambridge University Press, Cambridge.

Brown, H. P. and Hopkins, S. V., 2013. A perspective of wages and prices (Routledge Revivals). Routledge, London.

Cabrillana, N., 1968. La crisis del siglo xiv en Castilla. Hispania, 109, 245-258.

Cabrillana, N., 1972. Los despoblados en Castilla la Vieja. Hispània, 120, 31.

Campbell, B. M. S., 2016. The great transition. Climate, disease, and society in the late medieval world. Cambridge University Press, Cambridge.

Campo Gutiérrez, A. D., 2006. Mozos y mozas sirvientes en la Zaragoza de la segunda mitad del siglo xiv. Aragón en la Edad Media, 19, 97-112.

Carpentier, E., 1962. Autour de la Peste Noire: Famines et épidémies dans I'histoire du XIVe siècle. Annales E.S.C. 17, 1062-1092.

Casado Alonso, H., 1987. Señores, mercaderes y campesinos. Junta de Castilla y León, León.

Casado Alonso, H., 2009. ¿Existió la crisis del siglo xIv? Consideraciones a partir de los datos de la contabilidad de la catedral de Burgos. In: Val Valdivieso, M. I. del and Martínez Sopena, P. (eds.). Castilla y el mundo feudal: homenaje al profesor Julio Valdeón, vol. 3, pp. 9-25.

Castán Lanaspa, G., 2020. La construcción de la idea de la peste negra (13481350) como catástrofe demográfica en la historiografía española. Ediciones Universidad de Salamanca, Salamanca.

Castán Lanaspa, G. and Dueñas Carazo, S., 2006. Revisión de la incidencia de la peste negra (1348) en Navarra a través de un modelo matemático de población. Studia Histórica. Historia Medieval, 23, 275-314.

Clavero, B., 1974. Mayorazgo, propiedad feudal en Castilla (1369-1836). Siglo XXI, Madrid.

Cohn, S., 2007. After the Black Death. The Economic History Review, 60 (3), 457485.

Collantes de Terán Sánchez, A., 1980. Los efectivos humanos. In: Historia de Andalucía. Tomo III. Andalucía del Medievo a la Modernidad (1350-1504). Barcelona, pp. 75-98.

Cuvillier, J. P., 1969. La population catalane au XIVe siècle. Melanges de la Casa de Velázquez, 5, 159-187.

De Oliveira Ramos, L. A., 1963. Consequencias económicas da Peste Negra en Para o estudo da peste negra em Portugal. Actas do Congresso, Braga, pp. 220-229.

De Pleijt, A. M., and van Zanden, J. L., 2016. Accounting for the "Little Divergence". European Review of Economic History, 20 (4), 387-409.

Doñate Sebastiá, J. M., 1969. Datos negativos, referidos a la Plana de Castellón, en relación con la peste negra de 1348. In: La corona de Aragón en el siglo xIv, pp. 27-44.

Duro Peña, E., 1972. El monasterio de San Pedro de Rocas y su colección documental. Instituto de Estudios Orensanos Padre Feijóo, Orense.

Dyer, C., 1991. Niveles de vida en la Baja Edad Media. Crítica, Barcelona.

Epstein, S. R., 1994. Regional fairs, institutional innovation, and economic growth in late medieval Europe 1. The Economic History Review, 47 (3), 459-482.

Escalona, R. and Pérez, J., 1782. Historia del Real Monasterio de Sahagún: sacada de la que dexó escrita el padre maestro fr. Joseph Perez. Madrid.

Estepa Díez, C., 2003. Las behetrías castellanas. Junta de Castilla y León, Valladolid.

Falcón Pérez, M. I., 1985. La construction a Saragosse a la fin du Moyen Age. Cahiers de la Méditerranèe, 31, 73-93.

Feliu, G., 2004. La crisis catalana de la Baja Edad Media. Hispania, 64 (217), 435466.

Ferrari Núñez, A., 1958. Castilla dividida en dominios según el Libro de las Behetrías. RAH, Madrid.

Février, P. A., 1966. Villages désertés et histoire économique. XIe-X VII Ie siècle. SEVPEN, Paris.

Furió, A., 2013. La primera gran depresión europea (siglos xIV-xv). In: Llopis, E. and Maluquer de Motes, J. (eds.). España en crisis. Las grandes depresiones económicas, 1348-2012. Pasado y Presente, Barcelona, pp. 17-58.

García Sanz, A., 1981. Coyuntura agraria depresiva. In: García Sanz, A., Martín, J. L., Pascual. J. A. and Pérez Moreda, V. (eds.). Propiedades del cabildo segoviano, sistemas de cultivo y modos de explotación de la tierra a fines del siglo XIII. Ediciones Universidad de Salamanca, Salamanca, pp. 87-95.

Gautier Dalché, J., 1962. La peste noire dans les etats de la couronne d’Aragon. Bulletin Hispanique, 64, 65-80.

Guilleré, C., 1984. La Peste Noire à Gérone (1348). Annales del Instituto de Estudios Gerundenses, 27, 87-161.
Heers, J., 1976. Occidente durante los siglos xIV y xv. Aspectos económicos y sociales. Labor, Barcelona.

Hilton, R. H., 1980. Una crisi del feudalisme. L'Avenç, 33, 31-40.

Ibarra Téllez, D., 2007. La peste negra en Aragón a través de diversa documentación de Cancillería. Anales: Anuario del centro de la UNED de Calatayud, 15 (2), 125-136.

Igual Luis, D., 2007. ¿Crisis? ¿Qué crisis? El comercio internacional en los reinos hispánicos de la Baja Edad Media. Edad Media: Revista de Historia, 8, 203 223.

Iradiel, P., 1986. Familia y función económica de la mujer en actividades no agrarias. In: La condición de la mujer en la edad media: actas del coloquio celebrado en la Casa de Velázquez, del 5 al 7 de noviembre de 1984, pp. 223260

Iradiel, P., Moreta, S. and Sarasa, E., 1989. Historia medieval de la España cristiana. Cátedra, Madrid.

Koyama, M., Jedwab, R. and Johnson, N. D., 2019. Pandemics, places, and populations. CEPR Discussion Papers, DP13523.

Kelly, M., 2001. A History of the Black Death in Ireland. Tempus, London.

Koenigsberger, H. G., 1991. La Edad Media (400-1500). Crítica, Barcelona.

Krantz, O., 2017. Swedish GDP 1300-1560: A tentative estimate. Lund Papers in Economic History, 152

Kuchler, W., 1969. La influencia de la peste negra sobre la Hacienda Real. In: Actas del VIII Congreso de Historia de la Corona de Aragón, vol. 1. Valencia, pp. 65-70.

Ladero Quesada, M. A., 1986. Corona y ciudades en la Castilla del siglo xv. En la España Medieval, 5, 551-574.

Ladero Quesada, M. A., 1981. Población, economía y sociedad. Historia General de España y América, 5, 3-105.

Lamprecht, K., 1885-1886. Deutsches Wirtschaftsleben im Mittelalter. Leipzig.

Larenaudie, M. J., 1952. Les famines en Languedoc aux XIVe et XVe siècles. Annales du Midi, 64, 37-38.

López Alonso, C., 1978. Conflictividad social y pobreza en la Edad Media según las actas de las cortes castellano-leonesas. Hispania, 38, 475-568.

López de Meneses, A., 1959. Una consecuencia de la peste negra en Cataluña. Sefarad, 19 (1), 321-364.

Luttrell, A., 1966. Los hospitalarios en Aragón y la peste negra. Anuario de Estudios Medievales. 3, 499-514.

MacKay, A., 1977. Spain in the Middle Ages. From frontier to empire, 1000-1500. Palgrave Macmillan, London.

Malanima, P., 2009. Pre-Modern European economy. One thousand years (10th19th Centuries). Brill, Leiden.

Malanima, P., 2011. The long decline of a leading economy. European Review of Economic History, 15 (1), 169-219.

Martín Cea, J. C., 1986. El campesinado castellano de la Cuenca del Duero (s. XIIIxv). Junta de Castilla y Leon, Valladolid.

Martínez Carrillo, M. D. L. L., 1985. Manueles y Fajardos. La crisis bajomedieval en Murcia. Madrid.

Martínez Díaz, G., 1981. Libro becerro de las behetrías. Estudio y texto crítico. Centro de Estudios e Investigación San Isidoro, León.

Menjot, D., 1993. La main-d'œuvre des travaux publics en Castille méridionale au Bas Moyen Âge, l'exemple de Murcie. Razo, 14, 67-84.

Mitre Fernández, E. and Granda Gallego, C., 1985. La participación ciudadana en las Cortes de Madrid de 1391. En la España Medieval, 7, 831-850.

Mollat, M., Wolff, P. and Funes, S., 1976. Uñas azules, Jacques y Ciompi. Las revoluciones populares en Europa en los siglos xIv y xv. Siglo XXI, Madrid.

Monteano, P. J., 2001. La peste negra en Navarra. Príncipe de Viana, 62 (222), $87-120$.

Oliva Herrer, H. R., 2007. El mundo rural en la Corona de Castilla en la Baja Edad Media. Edad Media: Revista de Historia, 8, 295-328.

Pamuk, S., 2007. The Black Death and the origins of the "Great Divergence" across Europe, 1300-1600. European Review of Economic History, 11, 289-317.

Pérez Moreda, V., 1980. Las crisis de mortalidad en la España interior (siglos XVIXIX). Siglo XXI, Madrid.

Pérez Moreda, V., 1988. La población española. In: Artola, M. (ed.). Enciclopedia de Historia de España, vol. I: Economía. Sociedad, Madrid, pp. 345-431.

Pérez Moreda, V., 2002. La población española en tiempos de Isabel I de Castilla. In: Valdeón Baruque, J. (ed.). Sociedad y Economía en tiempos de Isabel la Católica. Valladolid: Instituto Universitario de Historia Simancas-Ámbito Ediciones, pp. 13-38.

Perroy, E., 1949. A l’origine d’une Économie contractée: les crises du XIVe siècle. Annales E.S.C., 4, 167-182.

Pretel Marín, A., 1982. Don Juan Manuel, señor de la llanura. Instituto de Estudios Albacetenses, Albacete.

Pladevall, A., 1962. La disminució de poblament a la Plana de Vich a mitjans del segle xIv. VI Asamblea d’Estudis Comarcals, Vich, pp. 23-35. 
Postan, M., 1981. Los fundamentos económicos de la sociedad medieval. In: Ensayos sobre agricultura y problemas generales de la economía medieval. Madrid, pp. 5-37.

Prados de la Escosura, L., Álvarez-Nogal, C. and Santiago-Caballero, C., 2020. Growth Recurring in Preindustrial Spain: Half A Millennium Perspective. CEPR Discussion Paper, DP 14479.

Prados de la Escosura, L. and Rodríguez-Caballero, C. V., 2020. Growth, Wars and Pandemics: Europe in the very long-run. CEPR Discussion Paper, DP 14816.

Ridolfi, L. and Nuvolari, A., 2020. L'histoire Immobile? A Reappraisal of French Economic Growth Using the Demand-Side Approach, 1280-1850, CEPR Discussion Paper, DP 14985

Robinson, W. C., 1959. Money, population and economic change in the late medieval Europe. Economic History Review, 12 (1), 63-76.

Rodríguez, A., 2011. Spain. In: Kitsikopoulos, H. (ed.). Agrarian Change and Crisis in Europe, 1200-1500. Routledge, London, pp. 167-203.

Rodríguez Molina, J., 1981. El Reino de Jaén en la Baja Edad Media. Universidad de Granada, Granada.

Romano, R. and Tenenti, A., 1977. Los fundamentos del mundo moderno. Siglo XXI, Madrid.

Rubio Vela, A., 1979. Peste negra, crisis y comportamientos sociales en la España del siglo xIv. Universidad de Granada, Granada.

Rubio Vela, A., 1987. Crisis agrarias y carestías en las primeras décadas del siglo XIV. El caso de Valencia. Saitabi. 37, 131-147.

Santamaría Arandez, A., 1969. "La peste negra en Mallorca”. En VIII Congreso de Historia de la Corona de Aragón. II: La Corona de Aragón en el siglo XIV. Valencia, vol. I, pp. 103-130

Sanz Fuentes, M. J., 1987. El ordenamiento de precios y salarios otorgado por Pedro I en 1351. Cuaderno de la villa de Écija. Estudio y edición. In: Homenaje al profesor Juan Torres Fontes, II. Murcia, pp. 1563-1574.

Schofield, P. R., 2013. Approaches to famine in medieval England. In: Benito i Monclús, P.(ed.). Crisis alimentarias en la Edad Media: modelos, explicaciones y representaciones. Milenio, Lleida, pp. 71-86.

Scheidel, W., 2017. The Great Leveler. Princeton University Press, Princeton.

Schreiner, J., 1948. Pest og prisfall i senmidedelalde, Oslo.

Sobrequés Callicó, J., 1970. La peste negra en la Península Ibérica. Anuario de Estudios Medievales, 7, 67-102.

Torres Fontes, J., 1981. Tres epidemias de peste en Murcia en el siglo XIV (134849). In: De Historia Medica Murciana. II. Las epidemias. Real Academia Alfonso X el Sabio, Murcia, pp. 9-66.
Trenchs Odena, J., 1969. La archidiócesis de Tarragona y la peste negra. La corona de Aragón en el siglo xIv, 1, 45-64.

Ubieto Arteta, A., 1975. Cronología del desarrollo de la peste negra en la Península Ibérica. Cuadernos de Historia. 5, 47-66.

Vaca Lorenzo, A., 1977. La estructura socioeconómica de la Tierra de Campos a mediados del siglo xiv. Publicaciones de la Institución Tello Téllez de Meneses, 39, 229-398.

Vaca Lorenzo, A., 1983. Una manifestación de la crisis castellana del siglo XIV. Studia Historica. Historia Medieval, 1, 157-166.

Vaca Lorenzo, A., 1984. La peste negra en Castilla. Studia Historica. Historia Medieval, 2, 89-107.

Vaca Lorenzo, A., 2001. La peste negra en Castilla: la primera et grande pestilencia que es llamada mortandad grande. Fundación, 4, 19-49.

Valdeón Baruque, J., 1966. Enrique II de Castilla. Universidad de Valladolid, Valladolid.

Valdeón Baruque, J., 1969. Aspectos de la crisis castellana en la primera mitad del siglo xIv. Hispania, 29, 5-24.

Valdeón Baruque, J., 1972a. La dinámica demográfica. In: Historia de España de Menéndez Pidal, pp. 79-97.

Valdeón Baruque, J., 1972b. La crisis del siglo xiv en Castilla. Revista de la Universidad de Madrid, 161-184.

Valdeón Baruque, J., 1984. Reflexiones sobre la crisis bajomedieval en Castilla. En la España Medieval, 5, 1048 y 1049.

Valdeón Baruque, J., 1989. La crisis del siglo xIv en la Corona de Castilla. In: Homenaje a Marcelo Vigil Pascual: la historia en el contexto de las ciencias humanas y sociales. Universidad de Salamanca, Salamanca, pp. 217-236.

Verlinden, C., 1938. La grande peste de 1348 en Espagne. Revue Belge de Philologie et d'Histoire, 17 (1-2), 103-146.

Vicens Vives, J., 1945. Historia de los remensas del siglo xv. Barcelona.

Vicens Vives, J., 1957. Historia social y económica de España y América. VicensVives, Barcelona.

Vilar, P., 1987. Cataluña en la España Moderna. Crítica, Barcelona.

Voigtländer, N. and Voth H. J., 2013. The Three Horsemen of Riches. Review of Economic Studies, 80, 774-811.

Zanden, J. L. van and van Leeuwen, B., 2012. Persistent but not consistent Explorations in Economic History, 49, 119-130.

Zulaica Palacios, F., 1995. Evolución de los precios y salarios aragoneses entre 1300-1430. Aragón en la Edad Media, 12, 123-152. 